\title{
Corrigendum
}

\section{Review: Converting nutritional knowledge into feeding practices: a case study comparing different protein feeding systems for dairy cows - CORRIGENDUM}

\author{
H. Lapierre, M. Larsen, D. Sauvant, M. E. Van Amburgh and G. Van Duinkerken \\ doi: 10.1017/S1751731118001763, published by Cambridge University Press, 24 August 2018.
}

Within the original article table 2 contained incorrect data. The correct representation of table 2 is shown here.

Table 2 Distribution of the requirement and the supply of digestible protein (g/day) for one example cow ${ }^{1}$

\begin{tabular}{|c|c|c|c|c|c|c|c|c|c|c|}
\hline \multirow[b]{2}{*}{ Feeding system ${ }^{2}$} & \multicolumn{6}{|c|}{ Requirement } & \multicolumn{4}{|c|}{ Supply } \\
\hline & Total & Scurf & Endogenous urinary & Metabolic faecal & Milk protein & Duo endo ${ }^{4}$ & Total & Undegraded dietary & Microbial & Duo endo ${ }^{4}$ \\
\hline CNCPS & 2501 & 14 & 100 & 621 & 1766 & & 2573 & 1101 & 1472 & \\
\hline DVE-1991 ${ }^{3}$ & 2104 & 14 & 100 & 386 & 1604 & & 2238 & 1120 & 1118 & \\
\hline DVE- $2007^{3}$ & 2119 & 14 & 100 & 386 & 1619 & & 2273 & 1034 & 1239 & \\
\hline INRA (2018) & 2248 & 13 & 203 & 411 & 1621 & & 2290 & 1142 & 1148 & \\
\hline NorFor & 2172 & 14 & 100 & 337 & 1722 & & 2085 & 738 & 1258 & 89 \\
\hline NRC (2001) & 2639 & 14 & 100 & 583 & 1766 & 176 & 2427 & 1070 & 1248 & 109 \\
\hline
\end{tabular}

${ }^{1}$ Average cow of Study 1 producing $38.3 \mathrm{~kg}$ of milk at 3.09\% true protein, $3.27 \%$ fat, eating $23 \mathrm{~kg} / \mathrm{day}$ of dry matter of the $16.5 \%$ CP diet (Olmos Colmenero and Broderick, 2006), at 120 days in milk, not changing BW $(589 \mathrm{~kg})$ and not gestating.

${ }^{2}$ CNCPS = Cornell Net Carbohydrate and Protein System, v 6.5 (van Amburgh et al., 2015); DVE = Dutch protein evaluation system, DVE-1991 (Tamminga et al., 1994) and DVE-2007 (VanDuinkerken et al., 2011); INRA (2018); NRC (2001); NorFor (2011).

${ }^{3}$ In DVE, the metabolic faecal is not included in the requirement and is excluded from the supply, as it is considered to be a consequence of the diet and not the animal.

For comparison purpose with the other feeding systems, this fraction has been added to the requirements and not removed from the supply in the current table.

${ }^{4}$ Duodenal endogenous flow.

The authors apologise for the error.

\section{Reference}

Lapierre H, Larsen M, Sauvant D, Van Amburgh ME and Van Duinkerken G 2018. Review: Converting nutritional knowledge into feeding practices: a case study comparing different protein feeding systems for dairy cows. Animal, first published online 24 August 2018. doi: 10.1017/S1751731118001763. 